\title{
The green factor: Unpacking green job growth
}

\author{
Nick SOFRONIOU* and Pauline ANDERSON**
}

\begin{abstract}
Drawing on data from the Labour Force Survey of the United Kingdom (2011-14), this article estimates the number of green jobs in Scotland and identifies change over time, using a methodological framework that can be applied to any region, based on ISCO-08 and $O^{*} N E T$. The findings highlight the value of charting changes in green jobs based on inclusive rather than "purist" definitions to better capture the broader impact of greening on jobs. The findings also indicate a need for greater analytical attention to issues of green job quality and inclusive green job growth.
\end{abstract}

Keywords: occupational classification, green jobs, job quality, occupational statistics, ISCO-08, O*NET, Scotland, UK.

\section{Introduction: Jobs in a greener economy}

Increasing global recognition that climate change and environmental resource depletion render a range of economic and other activities unsustainable has been the driver behind successively greener economic and social policies and agreements (see European Commission 2011; ILO 2015a; UNFCCC 2006). The United Nations Framework Convention on Climate Change (UNFCCC) was established in $1992^{1}$ and adopted the Kyoto Protocol in $1997,{ }^{2}$ which came into force in 2005. By 2006, some 164 countries and the European Community had signed the Protocol (UNFCCC 2006, 20) - a legally binding agreement designed to reduce emissions that contribute to global warming. ${ }^{3}$ This was followed in

* University of Warwick, Institute for Employment Research, email: nick_sofroniou@yahoo. ac.uk. $\quad * *$ University of Strathclyde, Department of Work, Employment and Organisation, email: pauline.anderson@strath.ac.uk (corresponding author).

Responsibility for opinions expressed in signed articles rests solely with their authors, and publication does not constitute an endorsement by the ILO.

1 United Nations: United Nations Framework Convention on Climate Change, adopted in New York on 9 May 1992, Treaty Series, Vol. 1771: 107.

2 United Nations: Kyoto Protocol to the United Nations Convention on Climate Change, adopted in Kyoto on 11 December 1997, Treaty Series, Vol. 2303: 162.

3 The Doha Amendment to the Kyoto Protocol in 2012 extended the initial agreement period (2008-12) to 2020 and set new emissions reduction targets. See UNFCCC (2006, 17-20) for a detailed history of the Convention and a timeline of key developments, including the Kyoto Protocol. For details regarding the Doha Amendment, see also https:/treaties.un.org/doc/Publication/CN/2012/ CN.718.2012-Eng.pdf, accessed 27 October 2020. 
2015 by the adoption of the Paris Agreement, with its aim to keep the global temperature rise this century at less than $2^{\circ} \mathrm{C}$ above pre-industrial levels. ${ }^{4}$ In order to support the shift to a greener, cleaner economy, the European Commission (2011) set out clear targets for Member States to reach by 2020, followed by more challenging targets for 2050. Together, these targets seek to reduce gas emissions, increase renewable energy sources and consumption, and increase energy efficiency. Measures specific to the United Kingdom of Great Britain and Northern Ireland include the introduction of the Climate Change Act $2008^{5}$ and the resultant creation of the Committee on Climate Change (CCC). The Scottish Climate Change Act $^{6}$ was passed in 2009 and the Scottish Government's specific pathway to a greener economy is notably more "ambitious" than that for the rest of the United Kingdom (CCC 2010,14). This ambition is the product of a range of pressing concerns, including the potential impact of severe weather and its disproportionate effects on vulnerable groups (for example, Scotland's ageing population and pockets of concentrated deprivation); key growth industries (food and drink, tourism, renewable energy) that are heavily reliant on natural resources; rare species vulnerable to climate change; and the fact that Scotland holds "[o]ver two-thirds of the UK's soil carbon stocks" (CCC 2011, 14). What is more, the Scottish National Party was able to form a Government in 2007 only with the support of two Green Party members of the Scottish Parliament, which clearly helped to drive forward the green agenda (Carter 2008, 229).

Embracing a greener economy not only helps address ecological challenges but is also seen as a key route out of the economic crisis triggered by the 2007-08 global financial crisis, providing nourishment for the shoots of longer-term economic prosperity and job growth (Bird and Lawton 2009; Eltham 2010; HM Government 2011; Martinez-Fernandez, Hinojosa and Miranda 2010; Pollin et al. 2008; Poschen and Renner 2015; UNEP 2008; Wei, Patadia and Kammen 2010). Whether the "green growth paradigm" (Martinez-Fernandez, Hinojosa and Miranda 2010,5) can deliver environmental sustainability and economic and job growth has been subject to increasing scrutiny (see Jessop 2012; Morriss et al. 2009; Pettinger 2017), yet such debates are largely ignored by policymakers, lured in particular by the promise of green job creation (see Masterman-Smith 2010, 320; Rodrik 2014, 489). Uncritical acceptance of optimistic estimates of green job growth is especially ill-advised, given that these are typically produced by organizations and groups with a "vested interest in the outcomes" (Morriss et al. 2009, 24). Nevertheless, better estimating of green job numbers and identifying patterns of growth (or indeed decline) is important to ensure effective local responses - such as adapting regional skills policies and provisions (Consoli et al. 2016, 1056). Charting green job growth also paves the way for more critical scrutiny of green job quality (Masterman-Smith 2010, 317) and a "just" transition to a greener economy (Pettinger 2017, 9-10).

In this light, this article estimates the number of green jobs in Scotland and identifies change over the period of study (2011-14). Scotland is used as the site

${ }^{4}$ United Nations: Paris Agreement, adopted in Paris on 12 December 2015, Registration No. 54113.

5 See https://www.legislation.gov.uk/ukpga/2008/27/contents.

${ }^{6}$ See https://www.legislation.gov.uk/asp/2009/12/contents. 
of administrative data collection because the Scottish Government has set ambitious emissions reduction targets; it aims to become "the green energy capital of Europe”, thus creating thousands of new green jobs (Scottish Government 2011, 14). However, the methodological framework that we present can be applied to any region. The main research questions are: how many green jobs are there in Scotland? What are the main patterns of growth or decline in green jobs? What are the implications of these changes? And what is the potential use value of the methodological framework adopted?

The next section considers the difficulty of defining green jobs and then outlines the Dierdorff et al. (2009) categorization of green jobs applied to the occupational taxonomy of the Occupational Information Network $\left(\mathrm{O}^{*} \mathrm{NET}\right)$, justifying its use for our study. The third section provides some context to the green job growth promise in Scotland; the fourth describes the methodological approach adopted; and the fifth section presents the findings from the analysis of administrative data for Scotland. The final, concluding section discusses the implications of these findings and the broader applicability of the methodological framework.

\section{Defining green jobs}

\subsection{The difficulties of definition}

The shift to a low-carbon, greener economy (see European Commission 2011; 2015 Paris Agreement ${ }^{7}$ ) is altering demand for some occupations and skills, while also creating new green occupations (Consoli et al. 2016; Dierdorff et al. 2009; Gagliardi, Marin and Miriello 2016; IRENA 2016; Poschen and Renner 2015; UNEP 2008). Anticipating green job growth is inherently difficult because it is partly linked to green investment, such as the quality of state/regional-level regulation and incentive schemes (Cedefop 2012; Rodrik 2014), and firm-level “eco-innovation” (Gagliardi, Marin and Miriello 2016). Even merely estimating green job numbers is challenging because there is no agreed definition of green jobs (ILO 2018, 135). Definitions tend to fall into one of two categories. The first can be described as adopting a "purist" approach, where green jobs tend to be narrowly defined in terms of their "green credentials" (UNEP 2008, 39; Dierdorff et al. 2009, 9) - that is, they are jobs that "contribute substantially to preserving or restoring environmental quality” (UNEP 2008, 39) and are typically located in the energy/renewables industries (Allan, McGregor and Swales 2017). The second category is host to much broader definitions that envelop the wider impact of greening on jobs (cf. Dierdorff et al. 2009, 11; Ge and Zhi 2016, 258-259; OECD 2012, 35). Compounding these definitional issues is the proposal that green jobs must also be "decent" or "good” jobs (ILO 2018, 187; UNEP 2008, 36):

Green jobs need to be decent work, i.e. good jobs which offer adequate wages, safe working conditions, job security, reasonable career prospects, and worker rights. People's livelihoods and sense of dignity are bound up tightly with their jobs. A job that is exploitative, harmful, fails to pay a living wage, and thus condemns workers to a life of poverty can hardly be hailed as green (UNEP 2008, 4).

7 See note 4 
From this perspective, and notwithstanding narrow versus broad definitional debates, green jobs are good-quality jobs (see Felstead et al. 2019; Findlay et al. 2017; CIPD 2017). ${ }^{8}$ Presumptions that green jobs are good-quality jobs are certainly widespread and not without foundation. Consoli et al. (2016), for instance, examined the differences between green and non-green jobs and suggest that new green jobs, as well as jobs that have substantially changed through greening, typically require higher-level skills and tend to be less routinized. Similarly, Muro, Rothwell and Saha (2011) note that green jobs are less likely to be low-skilled jobs. However, as Osterman and Chimienti's 2012 case study of weatherization (or weatherproofing) jobs in the United States of America helps illustrate, green jobs are not always good-quality jobs. Low wages, non-existent career ladders and lack of regional and national political will to improve the quality of these jobs were recurring themes, despite the jobs being "funded by federal dollars" (Osterman and Chimienti 2012, 411). The OECD (2012) observes that making inclusion in the definition of green jobs contingent on job quality often seems to be more of an aspirational rather than a definitional objective, pointing to the fact that many green jobs are indeed relatively low-quality jobs. What is more, it argues that the absence of a universally accepted definition of green jobs leads to widely varying green job estimates (OECD, 35-36). Yet it is important to develop a consistent approach to defining green jobs that supports the analysis of changing demand, not least because an "essential component" of green skills and labour market policies (Cedefop and OECD 2015, 15) will be to ensure there is a "just transition towards environmentally sustainable economies and societies for all” (ILO 2015a, 3). The classification of green occupations of the Occupational Information Network, or O*NET (Dierdorff et al. 2009), offers much potential here and is located firmly within the inclusive rather than the "purist" green definition camp.

\subsection{The $\mathrm{O}$ *NET classification of green occupations}

In addition to the direct job effects associated with the shift to a greener economy, there are indirect job effects, as well as "induced" job effects through investment in some areas and disinvestment in others (Cameron and van der Zwaan 2015, 162; Ge and Zhi 2016, 259). One repercussion of embracing the green economy is that a broad range of jobs will be subject to varying degrees of greenbiased change. What is needed is an occupation-based classification system that takes account of changes in the nature of work and worker requirements - extending not only to identifying new green jobs but also to examining the wider impact that a greener, cleaner economy is having on jobs. The $\mathrm{O}^{*}$ NET classification of green occupations accordingly serves as a useful, inclusive system that captures the impact on jobs beyond typically more narrow foci on new green jobs and/or, as is often the case, jobs exclusively located in the energy/renew-

8 Although there is no single accepted definition of job quality, there is general agreement that it is a multi-dimensional concept that envelops job-related factors (for example, skill utilization, discretion, control, training/development opportunities, pace of work and work environment) and employment-related factors (for example, pay, working time, job and employment security, pension and sick pay and worker representation), which are shaped and influenced by employer practices and macro-level factors (for example, social protection, national welfare systems, legislative and regulatory frameworks). 
ables industries (see Allan, McGregor and Swales 2017). Moreover, this broader, occupation-based classification system lends itself to opening up more critical debates around the quality of green jobs (see Masterman-Smith 2010, 317) and issues of an equitable and "just" transition (see OECD and Cedefop 2014, 43; Pettinger 2017, 9-10).

The $\mathrm{O}^{*}$ NET classification was developed by Dierdorff and his colleagues (Dierdorff et al. 2009) and distinguishes between three categories of "green occupations" in an attempt to show variation in the impact of greening on jobs. This system, they argue, is "essential for locating, describing, and forecasting potential workforce consequences of the green economy" (ibid., 10). These three green job categories are: new and emerging green occupations; green enhanced skills occupations; and green increased demand occupations (ibid., 4).

- New and emerging green occupations. The most closely aligned to "purist" definitions of green jobs, these are green occupations that are either completely new or have emerged from other occupations. For instance, a wind turbine service technician, engaged in the maintenance and repair of wind turbines, is a new occupation that has emerged in the transition to a greener economy (ibid., 119).

- Green enhanced skills occupations. These green occupations are not new but have been subject to substantial greening effects, altering existing work and worker requirements. Greening effects include the integration of green technology, new materials and changing legislative requirements, which can alter the required competencies and tasks, and the knowledge underpinning occupations. Architects, for example, are now subject to increased knowledge requirements relating to "energy efficient materials and construction, as well as skills associated with integrating green technology" into the design of buildings (ibid., 12).

- Green increased demand occupations. These green occupations are not subject to any significant change in work and worker requirements but are in increased demand due to greening. The context of work might change but the competencies and tasks remain the same. For example, there is an increasing demand for electrical power line installers as a result of efficiency-related infrastructure upgrades but the nature of work is broadly unchanged (ibid., 22).

\section{Estimating green jobs in Scotland}

As part of the implementation of the Roadmap 2050 to achieve a low-carbon economy in Europe (European Commission 2011), the Climate Change (Scotland) Act 2009 set out ambitious interim emissions reduction targets towards an overall 80 per cent reduction by 2050 . This ambition extends to the Scottish Government's investment in its economic vision and strategy, focused in particular on creating "many thousands of new jobs" in the renewables industry (Scottish Government 2011,13). Succumbing to the allure of new job creation in this industry is perhaps understandable, but the Scottish Government's narrow focus has detracted attention from the growth of new and emerging green occupations, green enhanced skills occupations and green increased demand occupations in other industries across the Scottish economy. While there is some 
evidence of greater recognition of the potential for green increased demand occupational growth - where "a growth in cycling could also mean an increase in jobs in local bike shops, supply chains and leisure and tourism outlets” (Scottish Government 2013, 187) - the Scottish Government continues to focus almost exclusively on estimating green job numbers in the renewables industry (see Audit Scotland 2013; O’Herlihy \& Co. 2014; Scottish Government 2017). As a result, there is a general failure to acknowledge that a greener economy is likely to have a much greater impact on jobs than narrow definitions of green jobs and/ or industry-specific foci might suggest. What is needed is an inclusive approach to estimating green jobs and charting green job growth that looks beyond these narrow definitions and specific industries.

There are clear benefits to an occupation-level, as opposed to an industry- or firm-level, analysis (see Knox and Warhurst, 2018). An occupation-based approach to estimating green jobs is especially useful at the regional level because it adds to local labour market intelligence and can therefore feed into and inform skills policies and provisions. Scotland has its own skills body (Skills Development Scotland) which supports a relatively “joined-up” regional skills system. There is, therefore, much potential to adapt to emerging developments and issues. Estimating green job numbers and charting green job growth can serve to alleviate job losses in some occupational areas by identifying "at risk" workers (see HM Government 2016, 3 and 11). An occupational lens also usefully paves the way for more critical exploration and analysis of green job growth - for instance, considering the extent to which green job growth is aligned with the Scottish Government's “good jobs”/“fair work”/“inclusive growth” agenda (see Scottish Government 2015 and 2019; see also Sissons, Green and Broughton 2019, 436).

\section{Methodology}

Our methodological approach, which can be applied to any region, brings together a number of existing components that support an examination of changes in the composition of each type of green job. The first component was developed on the basis of the United States national O*NET occupational and skill classification, which applies the 2010 United States Standard Occupational Classification (SOC). We then developed this approach using the 2008 version of the International Standard Classification of Occupations (ISCO-08) ${ }^{9}$ to enable more straightforward cross-national comparisons in the future - for example, using the European Union Labour Force Survey. ${ }^{10}$ Initially, occupations were classified into the ten ISCO-08 major groups, represented by a one-digit code. For a more detailed breakdown of information by occupation, the 130 ISCO-08 minor groups of occupations - represented by a three-digit code - were also examined. The methodology extends the work of Cambridge Econometrics, GHK Consulting and the Warwick Institute for Employment Research for the European Commission's Directorate-General for Employment, Social Affairs and Inclusion (DG Employment) to produce the report Studies on Sustainability Issues: Green Jobs;

\footnotetext{
9 See https://www.ilo.org/public/english/bureau/stat/isco/isco08/.

10 See https://ec.europa.eu/eurostat/web/microdata/labour-force-survey.
} 
Trade and Labour (Cambridge Econometrics, 2011). In their approach, each of the original US 2010 SOC codes and titles were matched to ISCO-88 in the DG Employment report using a smaller number of categories to ensure robustness of the mappings at the three-digit level of aggregation. This approach helps to reduce the problem of job categories that are considered separately under one classification and as a single group in another.

As an extended time series analysis is outside the scope of this article, given that the ISCO classification itself changes at regular intervals (ISCO-58, ISCO-68, ISCO-88, ISCO-08), we illustrate the approach over a four-year period to explore more short-term changes. The analysis focused on data from the UK Labour Force Survey (LFS) over the 2011-14 period. Mappings to the latest ISCO-08 classification system were applied to the available Scottish data from the LFS periods of 2011, 2012, 2013 and 2014, allowing tabulation at the level of 130 minor groups (three-digit), 43 sub-major groups (two-digit) and ten major groups (onedigit). Each participant in the LFS is visited five times at three-month intervals (waves); therefore, waves 1 and 5 were selected to avoid overlapping (duplicates). Following standard practice, ISCO-08 Major Group 0 (Armed forces occupations) and the nested subgroups were excluded from the analysis. Mappings of ISCO-08 categories at the three-digit level to the $\mathrm{O}^{*} \mathrm{NET}$ green job categories generate unique green occupation categories at this classification level (see table A1 in the Appendix). These three-digit minor groups can then be combined with the more aggregated groupings to explore, for example, the proportion of types of green occupation in each of the nine one-digit major groups: 1. Managers; 2. Professionals; 3. Technicians and associate professionals; 4 . Clerical support workers; 5 . Services and sales workers; 6 . Skilled agricultural, forestry and fishery workers; 7. Craft and related trades workers; 8. Plant and machine operators and assemblers; and 9. Elementary occupations. We calculated the percentage of each type of occupation aggregated into the nine ISCO-08 major groups, providing a straightforward solution to quantifying the number of jobs in each of the "new and emerging", "green enhanced" and "green increasing demand" occupations in the broad occupational groupings. This is particularly useful for regions with small populations, where the three-digit classification of 41 types of green occupation would be unreliable due to small counts in each category, as well as for reporting and presenting broad trends across the nine major groups.

Understanding broad trends by ISCO-08 major group also provides a useful (albeit crude) proxy for requisite skill and associated qualification levels (see ILO 2012, 12-16) given that these major groups are ordered into a hierarchy on this basis. Major Groups 1 (managers) and 2 (professionals) generally require the highest levels of skills and qualifications, while Major Group 9 (elementary occupations) requires the lowest.

\section{Green occupations: Description of the 2011-14 Scottish data}

Table 1 shows the percentage and number of green jobs in Scotland in 2014 by ISCO-08 major group. Although the vast majority of jobs (just over 70 per cent) are classified as "other", almost 30 per cent are classified as green, equating to 
Table 1. Percentage and number of jobs in green occupations in Scotland by ISCO-08 major group in 2014

\begin{tabular}{|c|c|c|c|c|c|c|}
\hline Occupational major group & $\begin{array}{l}\text { New and } \\
\text { emerging } \\
\text { (\%) }\end{array}$ & $\begin{array}{l}\text { Enhanced } \\
\text { skills } \\
\text { (\%) }\end{array}$ & $\begin{array}{l}\text { Increased } \\
\text { demand } \\
(\%)\end{array}$ & Other (\%) & Total (\%) & Number \\
\hline 1. Managers & 0.0 & 7.6 & 0.0 & 92.4 & 100 & 236611 \\
\hline 2. Professionals & 22.2 & 10.7 & 0.0 & 67.1 & 100 & 569873 \\
\hline $\begin{array}{l}\text { 3. Technicians and associate } \\
\text { professionals }\end{array}$ & 22.0 & 0.0 & 13.3 & 64.7 & 100 & 299143 \\
\hline 4. Clerical support workers & 0.0 & 0.0 & 31.9 & 68.1 & 100 & 268907 \\
\hline 5. Services and sales workers & 0.0 & 0.0 & 9.8 & 90.2 & 100 & 515368 \\
\hline $\begin{array}{l}\text { 6. Skilled agricultural, forestry } \\
\text { and fishery workers }\end{array}$ & 0.0 & 52.6 & 16.5 & 30.9 & 100 & 41556 \\
\hline $\begin{array}{l}\text { 7. Craft and related trades } \\
\text { workers }\end{array}$ & 0.0 & 33.5 & 34.2 & 32.3 & 100 & 237724 \\
\hline $\begin{array}{l}\text { 8. Plant and machine operators } \\
\text { and assemblers }\end{array}$ & 0.0 & 18.4 & 57.0 & 24.6 & 100 & 135209 \\
\hline 9. Elementary occupations & 0.0 & 3.2 & 0.0 & 96.8 & 100 & 233159 \\
\hline All occupations & 7.6 & 8.4 & 13.4 & 70.7 & 100 & 2543226 \\
\hline
\end{tabular}

Figure 1. Green occupations in Scotland by ISCO-08 major group in 2014 (percentages)

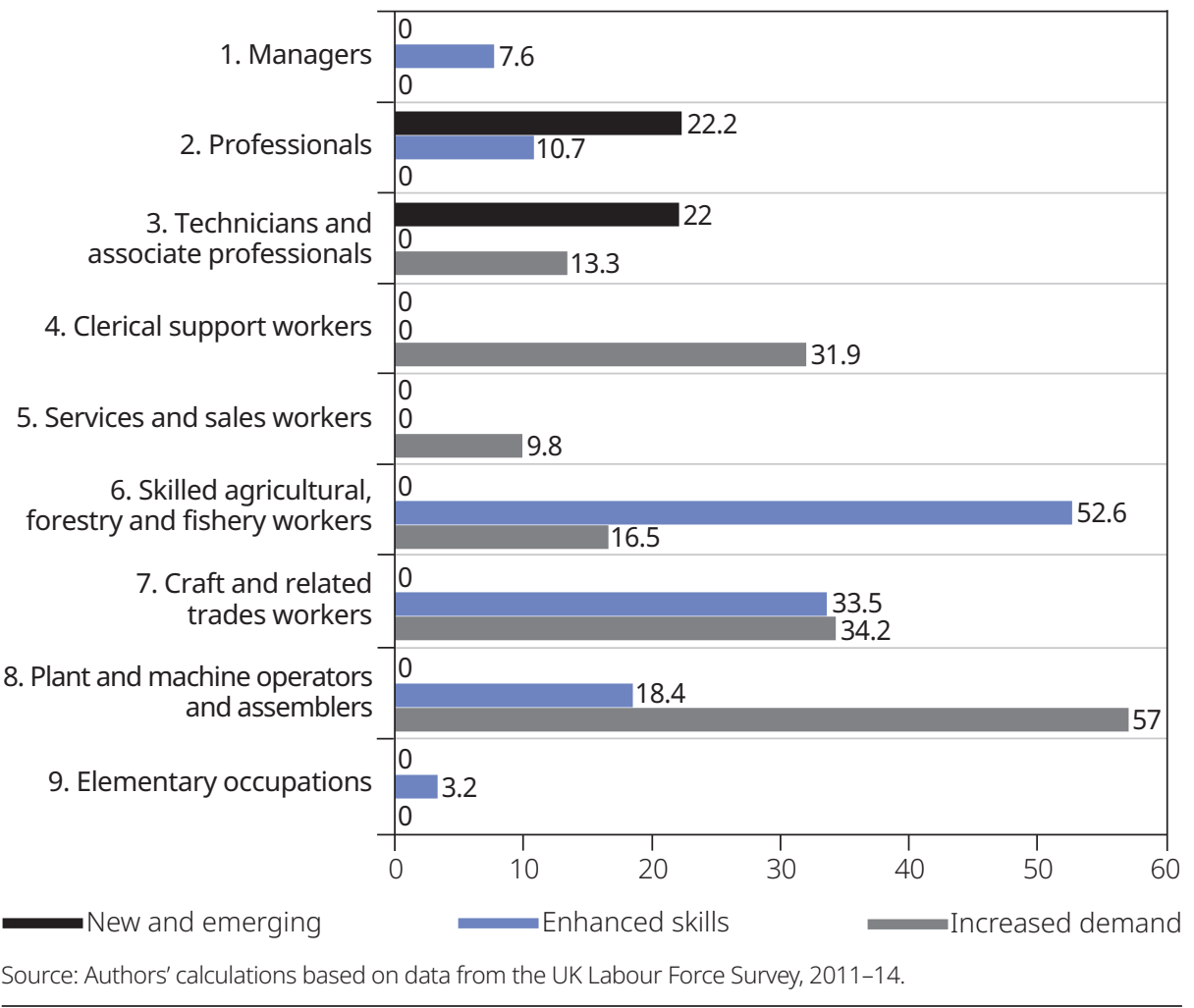


745,165 jobs. The proportions of jobs in new and emerging (7.6 per cent) and enhanced green skills (8.4 per cent) occupations are relatively low, whereas green increased demand occupations make up 13.4 per cent of all Scottish jobs. What is interesting is that Major Groups 6 (skilled agricultural, forestry and fishery workers), 7 (craft and related trades workers) and 8 (plant and machine operators and assemblers) have high proportions of jobs classified as either enhanced green skills and/or green increased demand occupations. Figure 1 plots the percentages of green occupations in 2014 by ISCO-08 major group. Of note is that new and emerging green occupations are exclusively located in Major Groups 2 and 3 and that green increased demand occupations tend to be concentrated further down the ISCO-08 major group hierarchy. The proportion of Major Group 8 occupations classified as green increased demand occupations is 57 per cent and the proportion of Major Group 6 occupations classified as enhanced green skills occupations is 52.6 per cent.

Between 2011 and 2014, there was an increase of 72,065 green jobs in Scotland. Figure 2 illustrates that most major groups experienced growth over the period, revealing some interesting patterns of growth/decline by green occupational category. In terms of job numbers, professionals experienced the greatest job growth in the new and emerging green occupations category $(23,561)$ but also a sharp decline in the green enhanced skills category $(-8,991)$. Technicians

Figure 2. Change in the number of jobs in green occupations in Scotland by ISCO-08 major group, 2011-14

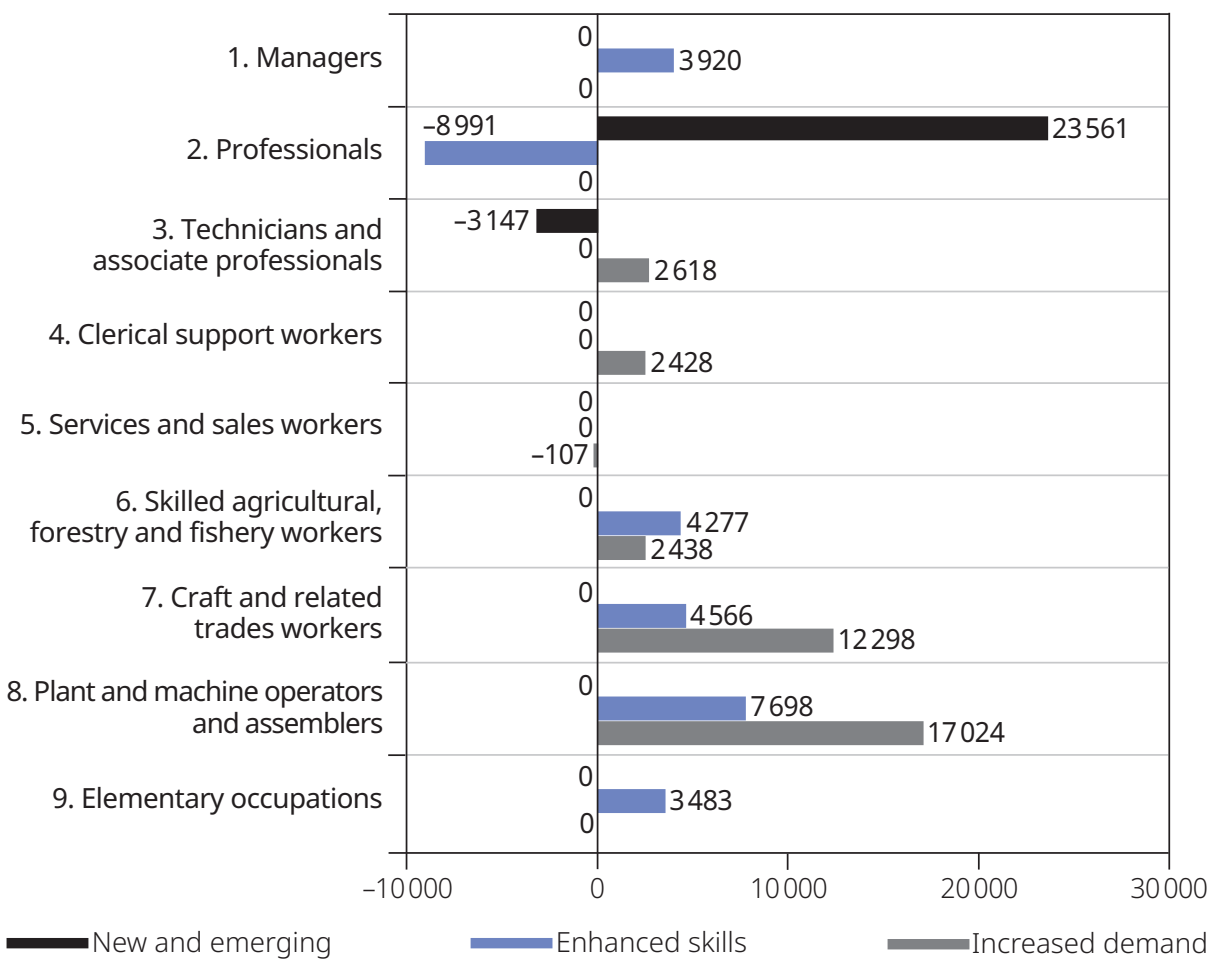

Source: Authors' calculations based on data from the UK Labour Force Survey, 2011-14. 
and associate professionals experienced the greatest overall net decline in job numbers (-530), primarily because of a decline in the number of jobs in new and emerging green occupations $(-3,147)$. Plant and machine operators and assemblers experienced the greatest overall growth $(24,722)$.

It is useful, however, to consider patterns of change by green occupation category in more detail, drilling down to the minor group level.

\subsection{New and emerging green occupations}

Table 2 shows the data for new and emerging green occupations by ISCO-08 major group over the 2011-14 period. Notably, all new and emerging green occupations are located in either Major Group 2 or Major Group 3. Professionals classified as new and emerging green occupations experienced job growth $(23,561)$ but there was a notable decline in new and emerging occupations among technicians and associate professionals $(-3,147)$.

Table 3 presents this data at the minor group level (ISCO-08 three-digit code level) and reveals that employment growth was concentrated among engineering

Table 2. Number of jobs in new and emerging green occupations in Scotland by ISCO-08 major group, 2011-14

\begin{tabular}{lrrrr}
\hline & 2011 & 2012 & 2013 & 2014 \\
\hline 1. Managers & 0 & 0 & 0 & 0 \\
2. Professionals & 103134 & 124504 & 123407 & 126695 \\
3. Technicians and associate professionals & 68871 & 65917 & 66567 & 65724 \\
4. Clerical support workers & 0 & 0 & 0 & 0 \\
5. Services and sales workers & 0 & 0 & 0 & 0 \\
6. Skilled agricultural, forestry and fishery workers & 0 & 0 & 0 & 0 \\
7. Craft and related trades workers & 0 & 0 & 0 & 0 \\
8. Plant and machine operators and assemblers & 0 & 0 & 0 & 0 \\
9. Elementary occupations & 0 & 0 & 0 & 0 \\
Total & 172006 & 190421 & 189974 & 192419 \\
Note: Any discrepancy in totals is due to rounding. & & & & \\
Source: Authors' calculations based on data from the UK Labour Force Survey, 2011-14. & & \\
\hline
\end{tabular}

Table 3. Number of jobs in new and emerging green occupations in Scotland by ISCO-08 minor group, 2011-14

\begin{tabular}{lrrrr}
\hline & 2011 & 2012 & 2013 & \multicolumn{1}{c}{2014} \\
\hline 214. Engineering professionals (excluding electrotechnology) & 33434 & 41687 & 44976 & 45899 \\
251. Software and applications developers and analysts & 43151 & 51712 & 46512 & 51832 \\
263. Social and religious professionals & 26549 & 31105 & 31919 & 28964 \\
311. Physical and engineering science technicians & 32924 & 27332 & 37373 & 32339 \\
335. Government regulatory associate professionals & 35947 & 38585 & 29194 & 33385 \\
Total & 172006 & 190421 & 189974 & 192419 \\
Note: Any discrepancy in totals is due to rounding. & & & & \\
Source: Authors' calculations based on data from the UK Labour Force Survey, 2011-14. & & \\
\hline
\end{tabular}


professionals and software and application developers/analysts, with a combined addition of 21,146 jobs over the period. The decline in the number of technicians and associate professionals (Major Group 3, highlighted in table 2) is the product of a relatively small reduction in the number of physical and engineering science technicians $(-585)$ and a much larger decline in government regulatory associate professionals $(-2,562)$.

\subsection{Enhanced green skills occupations}

Data on occupations by ISCO-08 major group illustrates how enhanced green skills occupations are slightly more evenly distributed across the major group hierarchy (see table 4). However, there appears to be something of a "missing middle", given that there are no such occupations in Major Groups 3, 4 and 5, whereas the proportions are particularly high in Major Groups 2 and 7. Over the 2011-14 period, all enhanced green skills occupations experienced net job growth - with the exception of professionals, which underwent a net decline of almost 9,000 jobs.

Drilling down to the minor group level, it becomes more apparent that changes are taking place within the Major Group 2 (professionals). As table 5 highlights, there has been a significant decline in the number of finance professionals $(-8,828)$ and a decrease in the numbers of life science professionals $(-1,894)$ and legal professionals $(-197)$. The number of mathematicians, actuaries and statisticians, on the other hand, more than doubled over the same period, albeit from a relatively low base. Other sizeable net increases or declines within the enhanced green skills occupations include: machinery mechanics and repairers (7,773); food and related products machine operators $(6,423)$; animal producers (4,277); building finishers and related trades workers $(-4,215)$; and refuse workers $(3,483)$. Not only did machinery mechanics and repairers experience a sizeable net increase over this period but this ISCO-08 minor group accounts for the largest group of enhanced green skills occupations (44,220 in 2014).

Table 4. Number of jobs in enhanced green skills occupations in Scotland by ISCO-08 major group, 2011-14

\begin{tabular}{lrrrr}
\hline & 2011 & 2012 & 2013 & 2014 \\
\hline 1. Managers & 14050 & 17504 & 13656 & 17970 \\
2. Professionals & 69843 & 60439 & 67173 & 60851 \\
3. Technicians and associate professionals & 0 & 0 & 0 & 0 \\
4. Clerical support workers & 0 & 0 & 0 & 0 \\
5. Services and sales workers & 0 & 0 & 0 & 0 \\
6. Skilled agricultural, forestry and fishery workers & 17566 & 18741 & 15089 & 21843 \\
7. Craft and related trades workers & 75095 & 65128 & 86170 & 79661 \\
8. Plant and machine operators and assemblers & 17119 & 16428 & 18928 & 24818 \\
9. Elementary occupations & 3878 & 3621 & 5088 & 7361 \\
Total & 197551 & 181862 & 206103 & 212503
\end{tabular}

Note: Any discrepancy in totals is due to rounding.

Source: Authors' calculations based on data from the UK Labour Force Survey, 2011-14. 
Table 5. Number of jobs in enhanced green skills occupations in Scotland by ISCO-08 minor group, 2011-14

\begin{tabular}{lrrrr}
\hline & 2011 & 2012 & 2013 & \multicolumn{1}{c}{2014} \\
\hline 112. Managing directors and chief executives & 1679 & 3937 & 2809 & 4263 \\
122. Sales, marketing and development managers & 12371 & 13568 & 10846 & 13708 \\
211. Physical and earth science professionals & 4225 & 5109 & 6476 & 4339 \\
212. Mathematicians, actuaries and statisticians & 1273 & 2033 & 3324 & 3086 \\
213. Life science professionals & 19936 & 18528 & 16586 & 18042 \\
241. Finance professionals & 32936 & 23494 & 25759 & 24108 \\
261. Legal professionals & 11473 & 11276 & 15028 & 11276 \\
612. Animal producers & 17566 & 18741 & 15089 & 21843 \\
712. Building finishers and related trades workers & 30056 & 24979 & 30434 & 25841 \\
722. Blacksmiths, toolmakers and related trades workers & 8592 & 7363 & 10863 & 9599 \\
723. Machinery mechanics and repairers & 36447 & 32786 & 44873 & 44220 \\
811. Mining and mineral processing plant operators & 3023 & 4739 & 4263 & 4715 \\
816. Food and related products machine operators & 9711 & 10907 & 9808 & 16134 \\
818. Other stationary plant and machine operators & 4386 & 783 & 4857 & 3969 \\
961. Refuse workers & 3878 & 3621 & 5088 & 7361 \\
Total & 197551 & 181862 & 206103 & 212503 \\
Note: Any discrepancy in totals is due to rounding. & & & & \\
Source: Authors' calculations based on data from the UK Labour Force Survey, 2011-14. & & \\
\hline
\end{tabular}

\subsection{Green increased demand occupations}

Data on jobs in green increased demand occupations by ISCO-08 major group shows that they are located in Major Groups 3, 4, 5, 6, 7 and 8 (see table 6). Major Group 4 (clerical support workers) has the greatest share of jobs $(85,809)$. Green increased demand occupations account for the largest proportion of green jobs, with an increase of 36,699 jobs over the 2011-14 period. Craft and related trades

Table 6. Number of jobs in green increased demand occupations in Scotland by ISCO-08 major group, 2011-14

\begin{tabular}{lrrrr}
\hline & 2011 & 2012 & 2013 & 2014 \\
\hline 1. Managers & 0 & 0 & 0 & 0 \\
2. Professionals & 0 & 0 & 0 & 0 \\
3. Technicians and associate professionals & 37150 & 47926 & 51201 & 39768 \\
4. Clerical support workers & 83382 & 83779 & 90773 & 85809 \\
5. Services and sales workers & 50559 & 45629 & 46162 & 50452 \\
6. Skilled agricultural, forestry and fishery workers & 4430 & 4855 & 8009 & 6868 \\
7. Craft and related trades workers & 68983 & 79357 & 75951 & 81281 \\
8. Plant and machine operators and assemblers & 60083 & 71048 & 63469 & 77108 \\
9. Elementary occupations & 0 & 0 & 0 & 0 \\
Total & 304587 & 332593 & 335564 & 341286
\end{tabular}

Note: Any discrepancy in totals is due to rounding.

Source: Authors' calculations based on data from the UK Labour Force Survey, 2011-14. 
Table 7. Number of jobs in green increased demand occupations in Scotland by ISCO-08 minor group, 2011-14

\begin{tabular}{lrrrr}
\hline & 2011 & 2012 & 2013 & 2014 \\
\hline 314. Life science technicians and related associate professionals & 988 & 1099 & 476 & 0 \\
333. Business services agents & 7399 & 9197 & 8552 & 5636 \\
343. Artistic, cultural and culinary associate professionals & 16983 & 25089 & 26603 & 19872 \\
351. Information and communications technology operations & 11781 & 12541 & 15570 & 14261 \\
$\quad$ and user support technicians & 75741 & 75629 & 75986 & 72420 \\
422. Client information workers & 7641 & 8150 & 14786 & 13389 \\
432. Material recording and transport clerks & 50559 & 45629 & 46162 & 50452 \\
541. Protective services workers & 4430 & 4855 & 8009 & 6868 \\
621. Forestry and related workers & 40138 & 45500 & 44528 & 46241 \\
711. Building frame and related trades workers & 7883 & 7246 & 9048 & 11801 \\
721. Sheet and structural metal workers, moulders and welders, & & & & \\
$\quad$ and related workers & 20963 & 26611 & 22375 & 23239 \\
741. Electrical equipment installers and repairers & 3794 & 8026 & 7459 & 8144 \\
813. Chemical and photographic products plant & & & & \\
$\quad$ and machine operators & 1829 & 1914 & 2215 & 4076 \\
814. Rubber, plastic and paper products machine operators & 6234 & 4825 & 4286 & 7941 \\
821. Assemblers & 2599 & 4019 & 4819 & 2274 \\
831. Locomotive engine drivers and related workers & 31077 & 37214 & 31239 & 38581 \\
833. Heavy truck and bus drivers & 14551 & 15049 & 13452 & 16091 \\
834. Mobile plant operators & 304587 & 332593 & 335564 & 341286
\end{tabular}

workers, and plant and machine operators and assemblers account for the bulk of this increase (with a net increase over the period of 12,298 and 17,025 jobs, respectively). Only one major group - the services and sales workers - experienced a decline in job numbers (-107).

Examining this data at the ISCO-08 minor group level highlights some interesting shifts over the 2011-14 period (see table 7). The number of life science technicians and related associate professionals, for instance, fell from 988 to 0 . Increases of note include the number of heavy truck and bus drivers $(7,504)$; building frame and related trades workers $(6,103)$; and material recording and transport clerks $(5,748)$. However, the minor group with the greatest share of jobs in 2014 - client information workers $(72,420)$ - experienced the largest decline over the period $(-3,321)$.

\section{Discussion and conclusions}

Within the limitations of the methodological framework (translated mappings

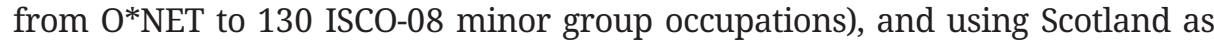
an illustrative example of its application, this article provides a snapshot of a recent four-year period, considering a range of occupations in terms of the changing requirements for new and emerging green occupations, enhanced green 
skills occupations and occupations with a green element in increasing demand. The analysis reveals that employment in green occupations in Scotland stood at 745,165 jobs in 2014 - an increase of 72,065 jobs since 2011 - and that green occupations accounted for 29.3 per cent of all Scottish jobs. It is worth noting that this figure is much higher than the figure resulting from the Scottish Government's narrow focus on "green jobs" in the renewables industry, which was reported as 43,500 in 2014 (Scottish Government 2017). The example of Scotland illustrates how narrow definitions of green jobs that focus only on their "green credentials" (UNEP 2008, 39) do not sufficiently capture the full impact of green-biased changes on jobs. Indeed, green increased demand occupations account for the greatest proportion of Scottish green jobs if the more inclusive O*NET classification is applied.

Given that ISCO-08 major groups provide a crude marker of skill and associated qualification levels (ILO 2012, 12-16), the findings show that new and emerging green occupations do indeed typically require higher levels of skills and qualifications (Consoli et al. 2016; Muro, Rothwell and Saha 2011). Enhanced skills and increased demand occupations tend to be located further down the occupational hierarchy, in jobs requiring lower-level skills and qualifications (ILO 2012, 14). In other words, all jobs in the new and emerging category are located in ISCO-08 Major Groups 2 and 3, while the majority of jobs in the enhanced skills and increased demand categories are located in Major Groups 6 and 8, respectively. Peters $(2014,258)$ suggests that policymakers should concentrate their efforts on supporting new and emerging green occupations rather than broader categories of green jobs because they "have some assurance they are investing in quality jobs". However, new and emerging green occupations in Scotland are predominantly engineering and IT-related occupations, areas in which women are markedly under-represented (Cohoon and Aspray 2006; Hill, Corbett and St Rose 2010). Indeed, the transition to a greener, cleaner economy may not be benefiting women and men equally. In fact, mounting "evidence points to green structural change reinforcing occupational trends that are less favourable for women" (OECD and Cedefop 2014, 43). Education and training pathways into new green occupations are also male-dominated (Cedefop, 2013) and there is some concern about the prospects of redressing this gender imbalance (ILO 2015b, 4) "unless measures are taken to train women in relevant skills” (ILO 2019, 10).

Regardless of aspirations to focus on "good-quality" green jobs and notwithstanding related unequal gender effects, a broad range of green policies are likely to have unintended consequences. Environmental policies and associated targets, for example, go some way to explain the growth in low-quality green jobs (see, for example, Gregson et al. 2016). These policies have generated demand for "low-paid, insecure and dangerous work such as much disassembly of obsolete ships and ICT equipment in South Asia” (OECD 2012, 35) and supported the rise in low-skilled, precarious and "dehumanizing" work in United States recycling plants (Econie and Dougherty 2019). The sustainability of some green jobs is also a matter of concern. The findings highlight a sharp decline in the number of new and emerging technicians and associate professionals between 2011 and 2014 (-3,147 jobs), and the longer-term prospects for some of these 
technical-level jobs are not sufficiently clear. For example, many technician-level construction and installation jobs - in contrast to operation and maintenance jobs - in wind and solar energy are "short-lived" (Bowen 2012, 6). Similarly, as part of a UK-wide initiative to install smart meters in all commercial and domestic premises by 2020 (BIS 2013), "smart meter installers" have emerged as a new green occupation and "an army of trainee smart meter installers are being recruited by energy suppliers” in Scotland (Smart Energy International 2017). Although the job is relatively well paid in Scotland and there is significant training investment ${ }^{11}$ - in contrast to weatherization jobs in the United States (Osterman and Chimienti 2012) - the longer-term job security and career prospects of these workers require further examination. In other words, what happens to this work and to these workers after all the smart meters have been installed?

Focusing on new and emerging green jobs only detracts from the broader impact of greening on jobs in general. Indeed, the green factor is permeating work and worker requirements in a number of ways. Many of these jobs may not fall into "purist" definitions or cannot reasonably be badged as "good" green jobs; however, they cannot be ignored. Instead, the growth of "good" and "bad" green jobs should be subject to increased academic and policymaking scrutiny. The proposal that jobs that are exploitative, poorly paid and insecure "can hardly be hailed as green" (UNEP 2008, 39) is a line of reasoning that could serve to airbrush many low-quality jobs out of the green jobs equation, rather than draw attention to questionable practices by employers and macro-level factors that are shaping the quality of green jobs (cf. Felstead et al. 2019; Findlay et al. 2017; CIPD 2017). Econie and Dougherty argue that there is a need for policies that "address labor conditions” $(2019,140)$. The Scottish Government should certainly be monitoring the extent to which efforts to promote green job growth align with its "inclusive growth" and "good jobs"/“fair work" agenda (see Scottish Government 2015 and 2019) and with the ILO's calls for a "just transition" and "decent work" (ILO 2015a). Indeed, "the right policies are needed to promote green industries while ensuring decent work within them” (ILO 2018, iii).

It is for this reason that the $\mathrm{O}^{*} \mathrm{NET}$ classification of green occupations is a useful approach to classifying green jobs in that it focuses attention on the variation in impact of greening on jobs, regardless of presumptions about job quality. At the same time, this classification system will need to adapt to the ongoing process of greening. Rather than merely label all non-green occupations as "other", it would be useful to develop a further category of "non-green reduced demand occupations" to identify and chart changes in occupations most at risk from greening. Nevertheless, as more jobs become subject to green-biased changes, the longer-term use value of the $\mathrm{O}^{*} \mathrm{NET}$ classification of green occupations is likely to diminish.

By interpreting an existing time series from the UK Labour Force Survey, this article presents an analytical exercise using high-quality empirical data to consider observed trends. The methodological framework can be applied directly to any region that implements the ISCO-08 classification of occupations in

11 See, for example, https://www.edfenergy.com/careers/current-opportunities/central-functions/ smart, accessed 9 November 2020. 
a forecasting context - for example, the Cedefop Skills Forecast for 28 EU Member States. ${ }^{12}$ It enables an earlier and more quantitative anticipation of job and skill needs, although it is dependent on the quality of the economic projections (that is, assumption-laden "forecasts" require sensitivity and robustness checks that are not necessary when using high-quality administrative data such as the Labour Force Survey). The approach is replicable given that table A1 provides mappings that adapt the Dierdorff et al. (2009) framework to the international occupational classification ISCO-08. For this reason, it offers considerable use value in that it demonstrates how to apply the $\mathrm{O}^{*}$ NET framework to any region. This simply requires mapping regional labour force survey data or occupational forecast data from a SOC to ISCO-08. ${ }^{13}$

The European Commission recommends that all EU Member States use ISCO-08 (or a national classification derived from ISCO-08 for statistical purposes) from 2011 onwards for all domains where statistics are cross-classified by occupation. ${ }^{14}$ Statistics for each Member State are provided using ISCO-08 in the European Statistical System. This is also the case for statistics generated by EU agencies, such as the Skills Forecast produced by the European Centre for the Development of Vocational Training (Cedefop) and Eurofound's European Working Conditions Survey. Therefore, researchers who obtain access to EU microdata (for example, the EU Labour Force Survey) will be able to immediately apply the methods presented in this article since they rely exclusively on ISCO-08 as the occupational classification. Projects making use of national data sets with local classification systems, such as the United Kingdom's SOC or France's professions et catégories socioprofessionnelles, will additionally require a transformation matrix from the local scheme to ISCO-08. As regards the United Kingdom, this article has demonstrated how its SOC can be mapped onto the ISCO framework, allowing the classification of green occupations to be applied to Scotland. In the case of France, Julie Falcon has developed the Social Position package for the R statistical software, ${ }^{15}$ which allows the automated conversion of PCS82 and PCS03 codes to ISCO-08, after which the methods presented in this article can be directly applied to generate the green occupational classifications. Generalizing these methods to investigate green occupations in other countries follows a similar path; all that is required is the transformation matrix and algorithm to convert the local occupational classification to ISCO, which will typically already be available. The method is also applicable at subregional level (for example, NUTS2 classification), provided that sufficient observations are available for each spatial unit, once each region is cross-classified by ISCO level and by any other variable of interest, such as industry or sector.

12 See https://www.cedefop.europa.eu/en/publications-and-resources/data-visualisations/skillsforecast, accessed 16 November 2020.

13 The Warwick Institute for Employment Research has a custom software module for the United Kingdom's SOC.

14 European Commission: Commission Recommendation of 29 October 2009 on the use of the International Standard Classification of Occupations (ISCO-08). Official Journal of the European Union 292: 31-47.

15 See https://CRAN.R-project.org/package=SocialPosition. 
There are a number of reports that provide informative regional case studies (see Cedefop 2012; Strietska-Ilina et al. 2011); the methodological framework presented in this article enables academics and policymakers to supplement this type of research with comparative quantitative regional estimates of the types of green jobs and their corresponding skill requirements. Comparative research has much potential to shed light on how the shift to a greener, cleaner economy is playing out in different regions and, therefore, to enhance empirical and theoretical understanding of green jobs. Comparisons between the four "home nations" of the United Kingdom would be particularly interesting, given that "patterns of spatially uneven development are deeply engrained in the UK's economic geography" (Sissons, Green and Broughton 2019, 437). Comparisons can also be undertaken at subregional/city level to support more fine-grained analyses that better anticipate changing demand. Longitudinal studies will also enable a more thorough examination of the sustainability of some green jobs. The methodological approach illustrated in this article provides a means by which regions may contribute to this discussion by usefully characterizing their labour forces in terms of green jobs, in a comparative context via the standard ISCO classification of occupations. It will also be important to break figures down to explore what is happening in specific occupations and the methodological approach will help highlight patterns of occupational change that warrant further investigation. More in-depth occupational case studies, similar to those undertaken by Osterman and Chimienti (2012) and Econie and Dougherty (2019), are needed to better unpack the issue of green job quality. Better profiles of green job incumbents are also needed. As Gregson et al. argue, we need to find out who is doing the "dirty work" in the greener economy - note, for example, that many poor-quality green jobs in Northern Europe are undertaken by "migrant labour, often from accession states" (2016, 541). Similarly, Terada's research on the export of recycling electronic wastes highlights that "poor men, women and children are being exposed to dangerous chemicals and work conditions in order to dismantle e-waste sent from developed countries” $(2012,158)$. In this light, there is a need to better understand geographical shifts/exports in dirty, dangerous green jobs, particularly from the Global North to the Global South.

\section{References}

Allan, Grant, Peter McGregor, and Kim Swales. 2017. "Greening Regional Development: Employment in Low-Carbon and Renewable Energy Activities”. Regional Studies 51 (8): $1270-1280$.

Audit Scotland. 2013. Renewable Energy, September 2013. Edinburgh.

Bird, Jenny, and Kayte Lawton. 2009. The Future's Green: Jobs and the UK Low-Carbon Transition. London: Institute for Public Policy Research.

BIS (Department for Business, Innovation and Skills) and Ofgem (Office of Gas and Electricity Markets). 2013. "Smart Meters: Information for Industry and Other Stakeholders”. https://www.gov.uk/guidance/smart-meters-information-for-industryand-other-stakeholders.

Bowen, Alex. 2012. “'Green’ Growth, ‘Green’ Jobs and Labor Markets”, Policy Research Working Paper No. 5990. Washington, DC: World Bank.

Cambridge Econometrics. 2011. Studies on Sustainability Issues: Green Jobs; Trade and Labour. Cambridge. 
Cameron, Lachlan, and Bob van der Zwaan. 2015. "Employment Factors for Wind and Solar Energy Technologies: A Literature Review”. Renewable and Sustainable Energy Reviews 45 (May): 160-172.

Carter, Neil. 2008. "The Green Party: Emerging from the Political Wilderness?” British Politics 3 (2): 223-240.

CCC (Committee on Climate Change). 2010. Scotland's Path to a Low-Carbon Economy. London.

- 2011. How Well is Scotland Preparing for Climate Change? London.

Cedefop (European Centre for the Development of Vocational Training). 2012. "Green Skills and Environmental Awareness in Vocational Education and Training”, Research Paper No. 24. Luxembourg: Publications Office of the European Union.

—. 2013. "Skills for a Low-Carbon Europe: The Role of VET in a Sustainable Energy Scenario", Research Paper No. 34. Luxembourg: Publications Office of the European Union.

Cedefop, and OECD (Organisation for Economic Co-operation and Development). 2015. Green Skills and Innovation for Inclusive Growth. Luxembourg: Publications Office of the European Union.

CIPD (Chartered Institute of Personnel and Development). 2017. "Understanding and Measuring Job Quality”, Research Report, Part 1: Thematic Literature Review. London.

Cohoon, Joanne McGrath, and William Aspray, eds. 2006. Women and Information Technology: Research on Underrepresentation. Cambridge, MA: MIT Press.

Consoli, Davide, Giovanni Marin, Alberto Marzucchi, and Francesco Vona. 2016. "Do Green Jobs Differ from Non-Green Jobs in Terms of Skills and Human Capital?" Research Policy 45 (5): 1046-1060.

Dierdorff, Erich C., Jennifer J. Norton, Donald W. Drewes, Christina M. Kroustalis, David Rivkin, and Phil Lewis. 2009. Greening of the World of Work: Implications for $O^{*} N E T 囚 S O C$ and New and Emerging Occupations. Raleigh, NC: National Center for O*NET Development.

Econie, Alexis, and Michael L. Dougherty. 2019. "Contingent Work in the US Recycling Industry: Permatemps and Precarious Green Jobs”. Geoforum 99 (Feb): 132-141.

Eltham, Ben. 2010. “Australia’s Green Economic Potential”, CPD Occasional Paper No. 10. Sydney: Centre for Policy Development.

European Commission. 2011. A Roadmap for Moving to a Competitive Low Carbon Economy in 2050. COM(2011) 112 final. Brussels.

Felstead, Alan, Duncan Gallie, Francis Green, and Golo Henseke. 2019. "Conceiving, Designing and Trailing a Short-Form Measure of Job Quality: A Proof-of-Concept Study”. Industrial Relations Journal 50 (1): 2-19.

Findlay, Patricia, Chris Warhurst, Ewart Keep, and Caroline Lloyd. 2017. "Opportunity Knocks? The Possibilities and Levers for Improving Job Quality”. Work and Occupations 44 (1): 3-22.

Gagliardi, Luisa, Giovanni Marin, and Caterina Miriello. 2016. "The Greener the Better? Job Creation Effects of Environmentally-Friendly Technological Change”. Industrial and Corporate Change 25 (5): 779-807.

Ge, Yeyanran, and Qiang Zhi. 2016. "Literature Review: The Green Economy, Clean Energy Policy and Employment”. Energy Procedia 88 (June): 257-264.

Gregson, Nicky, Mike Crang, Julie Botticello, Melania Calestani, and Anna Krzywoszynska. 2016. 'Doing the 'Dirty Work' of the Green Economy: Resource Recovery and Migrant Labour in the EU”. European Urban and Regional Studies 23 (4): 541-555.

Hill, Catherine, Christianne Corbett, and Andresse St Rose. 2010. Why So Few? Women in Science, Technology, Engineering, and Mathematics. Washington, DC: American Association of University Women.

HM Government. 2011. Skills for a Green Economy: A Report on the Evidence, October 2011. London. 
. 2016. Oil and Gas Workforce Plan, July 2016. London.

ILO. 2012. International Standard Classification of Occupations ISCO-08. Vol. 1, Structure, Group Definitions and Correspondence Tables. Geneva.

—. 2015a. Guidelines for a Just Transition towards Environmentally Sustainable Economies and Societies for All. Geneva.

- 2015b. Gender Equality and Green Jobs. Geneva.

—. 2018. World Employment Social Outlook 2018: Greening with Jobs. Geneva.

- 2019. Skills for a Greener Future: Key Findings. Geneva.

IRENA (International Renewable Energy Agency). 2016. Renewable Energy and Jobs: Annual Review 2016. Masdar City.

Jessop, Bob. 2012. "Economic and Ecological Crises: Green New Deals and No-Growth Economies”. Development 55 (1): 17-24.

Knox, Angela, and Chris Warhurst. 2018. "Occupations, the Missing Link? A New Theoretical and Methodological Approach to Product Markets, Skill and Pay”. Work, Employment and Society 32 (1): 150-168.

Martinez-Fernandez, Cristina, Carlos Hinojosa, and Gabriela Miranda. 2010. "Green Jobs and Skills: The Local Labour Market Implications of Addressing Climate change". Working document CFE/LEED. Paris: OECD.

Masterman-Smith, Helen. 2010. “Green Collaring a Capital Crisis?” Labour \& Industry 20 (3): 317-330.

Morriss, Andrew P., William T. Bogart, Andrew Dorchak, and Roger E. Meiners. 2009. "Green Jobs Myths", University of Illinois Law and Economics Research Paper Series No. LE09-001. Champaign, IL: University of Illinois College of Law.

Muro, Mark, Jonathan Rothwell, and Devashree Saha. 2011. Sizing the Clean Economy: A National and Regional Green Jobs Assessment. Washington, DC: The Brookings Institution.

OECD (Organisation for Economic Co-Operation and Development). 2012. "The Jobs Potential of a Shift towards a Low-Carbon Economy”, OECD Green Growth Papers 2012-01. Paris.

OECD, and Cedefop. 2014. "Greener Skills and Jobs”, OECD Green Growth Studies. Paris.

O’Herlihy \& Co. 2014. Employment in Renewable Energy in Scotland 2013. Glasgow.

Osterman, Paul, and Elizabeth Chimienti. 2012. "The Politics of Job Quality: A Case Study of Weatherization”. Work and Occupations 39 (4): 409-426.

Peters, David J. 2014. "Understanding Green Occupations from a Task-Based Approach". Applied Economic Perspectives and Policy 36 (2): 238-264.

Pettinger, Lynne. 2017. "Green Collar Work: Conceptualizing and Exploring an Emerging Field of Work”. Sociology Compass 11 (1): 1-13.

Pollin, Robert, Heidi Garrett-Peltier, James Heintz, and Helen Scharber. 2008. Green Recovery: A Program to Create Good Jobs and Start Building a Low-Carbon Economy. Washington, DC: Center for American Progress.

Poschen, Peter, and Michael Renner. 2015. "Green Jobs: Protecting the Environment Can Go Hand in Hand with Economic Prosperity and Job Opportunities”. Finance and Development 52 (4): 14-17.

Rodrik, Dani. 2014. “Green Industrial Policy”. Oxford Review of Economic Policy 30 (3): 469-491.

Scottish Government. 2011. Low Carbon Scotland: Meeting the Emissions Reduction Targets 2010-2022 - The Report on Proposals and Policies. Edinburgh.

- 2013. Low Carbon Scotland: Meeting the Emissions Reduction Targets 2013-2027The Second Report on Proposals and Policies. Edinburgh.

- 2015. Scotland's Economic Strategy: March 2015. Edinburgh. . 2017. “Green Jobs Increase”, 6 April 2017. https://news.gov.scot/news/green-jobsincrease. 
2019. “Employers Encouraged to Put 'Fair Work First”, 27 February 2019. https:// www.gov.scot/news/employers-encouraged-to-put-fair-work-first/.

Sissons, Paul, Anne E. Green, and Kevin Broughton. 2019. "Inclusive Growth in English Cities: Mainstreamed or Sidelined?” Regional Studies 53 (3): 435-446.

Smart Energy International. 2017. "Scottish College to Begin Training Smart Meter Installers”, 22 May 2017. https://www.smart-energy.com/regional-news/europe-uk/ scottish-college-smart-meter/.

Strietska-Ilina, Olga, Christine Hofmann, Mercedes Durán Haro, and Shinyoung Jeon. 2011. Skills for Green Jobs: A Global View. Geneva: ILO.

Terada, Christine. 2012. "Recycling Electronic Wastes in Nigeria: Putting Environmental and Human Rights at Risk". Northwestern Journal of International Human Rights 10 (3): 154-172.

UNEP (United Nations Environment Programme). 2008. Green Jobs: Towards Decent Work in a Sustainable, Low-Carbon World. Nairobi.

UNFCCC (United Nations Framework Convention on Climate Change). 2006. United Nations Framework Convention on Climate Change: Handbook. Bonn.

Wei, Max, Shana Patadia, and Daniel M. Kammen. 2010. "Putting Renewables and Energy Efficiency to Work: How Many Jobs Can the Clean Energy Industry Generate in the US?” Energy policy 38 (2): 919-931. 


\section{Appendix}

Table A1. Classification of relevant ISCO-08 minor groups by green occupation category

\begin{tabular}{ll}
\hline Green category & ISCO-08 classification (3-digit) \\
\hline Enhanced skills occupations & 112 Managing directors and chief executives \\
& 122 Sales, marketing and development managers \\
& 211 Physical and earth science professionals \\
& 212 Mathematicians, actuaries and statisticians \\
& 213 Life science professionals \\
& 241 Finance professionals \\
& 261 Legal professionals \\
& 333 Business services agents \\
& 612 Animal producers \\
& 712 Building finishers and related trades workers \\
& 722 Blacksmiths, toolmakers and related trades workers \\
& 723 Machinery mechanics and repairers \\
& 811 Mining and mineral processing plant operators \\
& 816 Food and related products machine operators \\
& 818 Other stationary plant and machine operators \\
& 961 Refuse workers
\end{tabular}

Increased demand occupations $\quad 314$ Life science technicians and related associate professionals

333 Business services agents

343 Artistic, cultural and culinary associate professionals

351 Information and communications technology operations and user support technicians

422 Client information workers

432 Material recording and transport clerks

541 Protective services workers

621 Forestry and related workers

711 Building frame and related trades workers

721 Sheet and structural metal workers, moulders and welders, and related workers

741 Electrical equipment installers and repairers

813 Chemical and photographic products plant and machine operators

814 Rubber, plastic and paper products machine operators

821 Assemblers

831 Locomotive engine drivers and related workers

833 Heavy truck and bus drivers

834 Mobile plant operators

New and emerging occupations

214 Engineering professionals (excluding electrotechnology)

251 Software and applications developers and analysts

263 Social and religious professionals

311 Physical and engineering science technicians

333 Business services agents

335 Government regulatory associate professionals

Source: Authors' mappings of the Dierdorff et al. (2009) categorization of green occupations (based on the O*NET occupational taxonomy) to ISCO-08 